\title{
Managerial perceptions of corporate sustainability reporting determinants in Nigeria
}

\author{
Obiamaka Adaeze Nwobu \\ Francis Iyoha \\ Department of Accounting, Covenant University, Nigeria \\ Akintola Owolabi \\ Lagos Business School, Pan-Atlantic University, Lagos, Nigeria
}

\section{Key words}

Coercive; Institutions; Mimetic; Normative; Organizations; Sustainability Reporting

\begin{abstract}
This study investigated managerial perceptions of the determinants of sustainability reporting in Nigeria. The rationales that managers construct around institutional pressures in relation to sustainability reporting constitute an under explored area in research. A survey research design was employed. A questionnaire was designed for the purpose of data collection and copies were administered to 81 companies in oil and gas, banking, industrial goods and consumer goods sectors in Nigeria. The results showed that corporate respondents opined that a mix of factors - coercive, normative and mimetic factors actually influence sustainability reporting of companies.

The findings showed that corporate actors attributed higher values to initiation from the company chief executive officer (CEO) and investors' concern with long-term performance of the business. Interestingly, regulatory pressures and employee training were found to have higher mean scores than pressures arising from corporate membership of external governance bodies, total asset base and foreign operations. Results from factor analysis showed that respondents opined that sustainability reporting was influenced by a mix of coercive, normative and mimetic factors. Pearson correlation between the level of sustainability reporting and coercive, normative and mimetic pressures showed significant association between the level of sustainability reporting and coercive and normative pressures.

This study identified that a number of pressures combine to influence sustainability reporting. The rationales attributed to the factors could be a pointer to the areas that members of the organizational field need to improve upon to enable companies to provide reliable sustainability reporting and disclosures. This study contributes to the literature by focusing on aspects of the organizational field or environment of business that can aid improvements in the quantity and quality of sustainability reporting. This aspect of research is yet to be undertaken in the Nigerian context.
\end{abstract}

Corresponding author: Obiamaka Adaeze Nwobu

Email addresses for corresponding author: obiamaka.nwobu@covenantuniversity.edu.ng

First submission received: 12th April 2017

Revised submission received: 29th July 2017

Accepted: 31st August 2017

\section{Introduction}

Developments in businesses worldwide indicate that it is important for companies to integrate sustainability aspects into their corporate reporting. According to Baron (2014), this is because businesses are operating in a world embattled with environmental and social challenges, making it imperative for business stakeholders to be informed about their responsibility efforts. Baker and Bettmer (1997) note that there are other issues such as wealth distribution, social justice, political ideology and environmental degradation that is within the purview of accounting. These issues affect business operations and society, and have led to clamors that organizations should report and be accountable for their actions particularly environmentally, socially and economically.

Muskawa (2014) identifies two schools of thought in the practice of corporate governance namely shareholders and stakeholders' model. The first school of thought argues that shareholders have financial stake in a business and their interests should be safeguarded by corporate governance structures such as 
company directors, board committees and chief executive officer. The second school of thought posits that governing an organization is not expected to be for the interests of shareholders only and no stakeholder should be ignored. This has resulted in the stakeholder model of corporate governance which emphasizes the need for companies to consider their impact on shareholders, suppliers, community, employees, and trade unions, society at large, amongst others.

According to Fremond (2000), businesses exist to serve a wider range of interests. The interests of stakeholders need to be taken into consideration to achieve balance between profitability and other aspects of organizational performance. Muswaka (2014) notes that stakeholder model of corporate governance can balance a company's pursuit of short-term profit and social justice. This is because businesses have responsibilities towards their internal and external stakeholders. According to Global Reporting Initiative (2013), sustainability reporting is a way of measuring, disclosing and being accountable to organizational stakeholders. Accountability to these stakeholders is important because of the risks that could arise from ignoring them. Kaspereit and Lopatta (2011) note that the risks arising from social and environmental impacts of business operations should not be ignored because they can impair profits and reduce shareholder value.

There are a host of factors that can influence sustainability reporting and related aspects such as social reporting, environmental reporting and integrated reporting. According to studies such as Adams (2002), Baele (2012) and Mitra, Agrawal \& Ghosh (2015), these factors stem from both the internal and external organizational environment. Adams (2002) notes these factors can determine the extensiveness, quality and quantity of reporting by companies. Furthermore, managers of companies are corporate actors whose perceptions of reporting in terms of its benefits and costs can influence the level of companies' engagement. Baele (2012) notes that companies where the chief executive officers perceive social responsibility reporting to be important engage in more reporting than the CEOs who did not perceive such reporting as important. In the view of Mitra et al. (2015), perceptions of managers about sustainability reporting influence the level of reporting. Managers also opine that lack of legal framework and best practice guidance is responsible for low engagement of companies in sustainability reporting. This approach to studying corporate social reporting and related areas such as sustainability reporting and integrated reporting provides a forum to engage with decision makers in the companies. Accessing data from the secondary sources such as corporate annual reports and websites may not be able to ascertain the reason for companies' engagement in sustainability reporting and perceptions of managers about the factors in the business environment that could be responsible for a companies' engagement in sustainability reporting.

In Nigeria, Asaolu, Agboola, Ayoola and Salawu (2011) find that sustainability reporting is a voluntary form of reporting. However, their study is premised on multinational oil and gas companies alone. They also note that there is no legislation guiding what companies report. The finding gives opportunity to engagement-based studies that can identify the behavior, attitudes and mind-sets of decision makers in companies in relation to factors in the internal and external business environment that influence the level of reporting of companies. In the view of Adams and Larrinaga-Gonzalez (2007), by engaging with corporate actors, organizational change in improved sustainability performance can be achieved. Drawing from their position, this study argues that manager rationales towards factors in the business environment can be a pointer to areas that steer companies to engage in sustainability reporting.

The business environment otherwise known as the institutional environment includes other companies in the industry, stakeholders, professional accounting firms, foreign presence, and bodies such as United Nations Environment Programme (UNEP), United Nations Global Compact (UNGC) and global oil and gas industry association for environmental and social issues (IPIECA).

This paper aims to broaden the literature on sustainability reporting by examining the perceptions of corporate managers towards institutional factors with a view to categorizing them. This area of research is under explored compared to studies that have examined corporate characteristics in relation to sustainability reporting. This research contributes to the sustainability reporting literature by assessing the determinants of sustainability reporting from the perspective of corporate managers. This interpretive approach to study the determinants of sustainability reporting can identify corporate managers' views of institutional factors in relation to sustainability reporting. The findings from this research should be able 
to assist institutions improve on their support for sustainability reporting. The research questions this study intends to answer is: what are the factors that influence sustainability reporting in Nigeria from the perception of corporate respondents?

\section{Main body}

\subsection{Determinants of Sustainability Reporting}

From a new institutional theory perspective (DiMaggio \& Powell, 1983), the members of an organization's external environment exert different pressures on an organization's reporting and disclosure practices (including sustainability reporting). This makes the study of the factors influencing sustainability reporting imperative to decipher how they combine at a point in time to influence organizations. These factors have been broadly grouped under three headings namely coercive, normative and mimetic pressures (Bebbington, Higgins \& Frame, 2009; Farneti \& Rammal, 2013). Coercive pressures have been argued to be a formidable force in leading companies to adopt a reporting practice. According to Hendey (2013), by withdrawing financial resources from business organizations that do not comply with certain rules and regulations, organizations can be forced to adapt a behavior or policy. Also, coercive pressures make organizations comply with certain disclosure and reporting practices because of the potential for reward or threat of punishment. Consequently, codes of corporate governance, Securities and Exchange Commission Laws, Central Bank Laws pertaining to sustainability reporting are coercive pressure mechanisms that influence companies' practices. Studies (Jalaludin, Sulaiman \& Ahmad, 2011; Goswami \& Lodhia, 2012) find that coercive pressures influenced reporting practices.

Normative pressures occur through the influence of professional networks that give room for certain reporting practices to permeate the business organization where such networks exist. For example, such pressures could arise from accounting firms, bodies that develop codes of conducts for sustainability reporting, professional accounting associations, amongst others. The more the networking of professionals or other bodies that brings companies together, the more the likelihood of increased reporting practices among such companies where those professionals are domiciled. It has also been argued by Jalaludin et al. (2011) that such professionalism stimulates education among the members of such professional circles.

Mimetic pressures have been examined in the literature. They can arise in varying forms. For example, mimetic pressures can emanate from copying best practices of those business organizations that are perceived as successful. They can also arise when a business organization copies reporting practices of a foreign affiliated company in order to access certain benefits. In addition, such foreign affiliated companies are prone to adhere to the parent company's reporting practices and host country requirements (Sufian, 2012). Therefore, this can increase the chances of improved reporting practices by the locally-based company that is affiliated with a foreign company.

Asaolu, Agboola, Ayoola and Salawu (2011) find that sustainability reporting is a voluntarily practice by multinational oil and gas companies in Nigeria. Their study also finds deficiencies in sustainability reporting as there is no guidance through legislation. Compared to their foreign affiliates, multinational oil and gas companies operating in Nigeria do not report on some aspects of sustainability reporting. Interestingly, oil and gas companies are environmentally-sensitive. The finding of Asaolu et al. (2011) is not in tandem with theoretical expectations as parent companies do not make sustainability reporting compulsory. Studies such as Amran \& Devi (2008) and Sufian (2012) find no influence of foreign affiliates on social reporting. The implication of their findings is that companies that have foreign affiliation do not have more social disclosures.

Most of the aforementioned studies are based on data gathered from secondary sources such as annual reports, sustainability reports and corporate websites. However, studies (Adams, 2002; Kaspersen, 2013; Krongkaew-Arreya \& Setthasakko, 2013) have argued for the need to assess institutional pressures through engagement with managers in business organizations. The findings from the literature on engagement-based studies in the area of sustainability reporting are not conclusive. Support and commitment from a company's chief executive officer is crucial to achieving the objectives of sustainability reporting. According to KPMG (2008), corporate disclosures and reporting are examined by the chief executive officer in order to mitigate the risks associated with statements made. Adams and Frost (2008) also concur that the chief executive officer of an organization is responsible for the development of Key Performance Indicators (KPIs) relating to sustainability performance. 
The company chair is in a position to approve budget allocations relating to performance indicators of sustainability reporting (Krongkaew-Arreya \& Setthasakko, 2013). Also, Chief Executive Officers (CEOs) can convince information users who monitor the organization by disclosing or reporting more to justify their position. New managers have been found to disclose more governance information to convince shareholders' monitoring (Mohd-Saleh, Mohd-Sanusi, Abd-Rahman \& Bukit, 2012). There is need for senior executives to demonstrate more commitment to sustainable practices and development (Sciulli, 2011). The pressure from the board of directors is another issue that has been identified in engagement-based studies in sustainability reporting. Corporate governance and sustainable development issues (including sustainability reporting) have been examined as separate fields of inquiry and less attention has been paid to the interactions between the two (Ricart, Rodriguez \& Sanchez, 2004). Business organizations are moving from minimizing agency conflicts (between principalsowners/shareholders and agents/managers) to issues of corporate transparency and accountability to the different business stakeholders.

Accountability towards shareholders is displayed in financial terms, showing them the profit that has been made by the injection of resources into the business. It is on the basis of the need to expand the current definition of accountability that a number of corporate governance codes in Africa for example are redefining their focus towards stakeholders (King III Code of Corporate Governance, Johannesburg, South Africa; Securities and Exchange Commission 2011 Code of Corporate Governance, Nigeria). In aforetimes, codes of corporate governance have adopted an agency theory perspective which seeks to reconcile business manager and shareholder conflicts. This has changed because best practice in corporate governance is characterized by increased stakeholder-oriented focus (Brennan \& Solomon, 2008).

Employee training is another internal factor that can influence corporate sustainability reporting. Training of employees is associated with costs. Aspects that are usually covered by employee training are the sustainability reporting process, stakeholder engagement, content of sustainability reports, monitoring the information that sustainability reporting covers, available guidelines that can be used for a sustainability report. Education and training of employees is an aspect in the implementation phase for organizations that subscribe to the ISO14000 series. ISO14000 is a group of standards related to environmental management. This training helps employees to be aware, implement, document and audit their environmental management systems. This is one of the issues in ensuring an adequate corporate sustainability strategy.

The accountability that financial results of a business organization communicate is an important aspect of corporate transparency that cannot be ignored. Financial results alone cannot determine corporate value. Sustainability issues could contribute to the value of business organizations. In order to improve the content of sustainability reports, external pressures and organizational context have roles to play in the transformation process. An unanswered question is how these factors can be assessed and modeled. There is not much discussion on corporate sustainability reporting arising from conformity to external pressures and organizational contexts in Nigeria.

\subsection{Materials and Methods}

In line with prior studies (Belal and Cooper, 2011: Krongkaew-arreya and Setthasakko, 2013) that examine the perceptions of managers towards corporate disclosures as well as the factors responsible for them, the current study employs a survey research design. The survey research design is appropriate because of its ability to solicit responses first-hand from managers and assess managers' rationales towards institutional pressures. According to the Nigerian Stock Exchange (2015), there are 15 universal banks, 24 companies in the industrial goods sector, 28 companies in the consumer goods sector and 14 companies in the oil and gas sector. This results in a population of 81 companies. 81 copies of questionnaire were administered to these companies and 54 companies responded to the survey. The questionnaire is made up of three sections namely A, B and C. In Section A, respondents are required to rate the importance of 22 factors in influencing sustainability reporting on a scale of 'Extremely Important', 'Important', 'Slightly Important' and 'Not Important'. In Section B, respondents are required to rate the actual influence of the factors on a scale of 'Strongly Agree', 'Agree', 'Disagree' and 'Strongly Disagree'. In Section C, respondents are required to rate the level of sustainability reporting, their industry affiliation, department, highest academic qualification, professional qualification and number of 
years of service to the organization. The respondents are required to respond on a scale of 'Strongly Agree', 'Agree', 'Disagree', 'Strongly Disagree' to 22 statements. The full description of the institutional pressure factors are in Appendix I. The data is analyzed using descriptive statistics and factor analysis. Descriptive statistics has been used in prior studies (for example, Belal and Cooper, 2011; Selvanathan, 2012) to ascertain the mean scores of responses to a particular statement or question in a survey instrument. Factor analysis is also used to ascertain how the factors can be grouped based on the respondents' perceptions (for example, Selvanathan, 2012). The data is analyzed using Statistical Package for Social Sciences (SPSS).

\section{Findings}

The response rate in this study is approximately 67 per cent. In line with Jalaludin, Sulaiman and Ahmad (2011), a comparison of the ten earliest and latest responses was carried out to determine the equal variance estimates between both classes of responses for all the variables. Results of independent samples t-test shows that the p-value is greater than 0.05 . Thus, it is concluded that there are no significant differences between the early and late responses for the variables (Appendix III). In order to test for reliability of the scale used to gather data used in this study, Cronbach's alpha test was conducted on the items in the questionnaire. The Cronbach's alpha coefficient is 0.923 , and implies very good internal consistency of the scale based on Pallant (2011). The results of this study are presented in two aspects namely descriptive statistics (mean and standard deviation) and factor analysis. The mean scores are necessary to know how the respondents responded to the factors from internal and external organizational environment. Factor analysis is used to examine the structure underlying the factors identified in the literature based on the responses retrieved.

Table 1 shows the mean scores of responses to the factors influencing sustainability reporting. The initiation from chief executive officer factor and investors' concerns with long-term performance of the business organization each has mean scores of 3.482 and standard deviation of 0.613 . Respondents' rate SEC code of corporate governance, employee training by organizations, CBN sustainability banking principles and foreign lenders higher than awards given to organizations for sustainability performance, professional accounting association training of accounting professionals, corporate membership of external governance bodies, total asset base of a business organization, presence of a business organization in a foreign country. The results of this study are also interpreted in line with new institutional theory. Coercive isomorphism has a mean score of 3.250 and this shows that respondents opine they face a high level of institutional pressure through stakeholders - investors, consumers, regulators and finance providers. Also, respondents opine that mimetic pressures influence sustainability reporting (mean score of mimetic pressure is 3.083). However, the respondents perceive that sustainability reporting is influenced by a moderate level (mean score of normative pressure is 3.182) of institutional pressure arising from professionalism. 


\begin{tabular}{|l|c|c|}
\hline Factors & Mean & Std. Deviation \\
\hline Initiation from Chief Executive Officer of organization & 3.482 & .613 \\
\hline Pressure from the Board of Directors & 3.185 & .729 \\
\hline Employee Training on sustainability reporting by business organizations & 3.333 & .727 \\
\hline Professional Accounting Association Training of Accounting Professionals & 3.074 & .866 \\
\hline Professional Accounting Firms Training of Accounting Professionals & 3.167 & .795 \\
\hline Investors' concem with long-term performance of the business organization & 3.482 & .606 \\
\hline Securities and Exchange Commission (SEC) Code of Corporate Governance & 3.407 & .687 \\
\hline Central Bank of Nigeria (CBN) Sustainability Banking Principles & 3.259 & .678 \\
\hline Successful Industry Leaders' engaging in sustainability reporting & 3.167 & .818 \\
\hline Consumers' interest in sustainable products and services of an organization & 3.241 & .775 \\
\hline Revenue base of a business organization & 3.148 & .833 \\
\hline Total asset base of a business organization & 3.037 & .823 \\
\hline Foreign lenders' emphasis on approving loans on the basis of sustainability & 3.259 & .732 \\
\hline Local lenders' emphasis on approving loans on the basis of sustainability & 3.167 & .720 \\
\hline Presence of a business orgarization in a foreign country & 3.000 & .847 \\
\hline Corporate membership of external govemance bodies & 3.056 & .878 \\
\hline Human resources on sustainability & 3.130 & .778 \\
\hline Employees' attitude towards sustainability reporting & 3.130 & .972 \\
\hline Accounting firms' Provision of Assurance Services on sustainability reporting & 3.167 & .771 \\
\hline Use of assurance services on sustainability reporting by business organizations & 3.148 & .810 \\
\hline Rating of business organizations on the basis of sustainability performance & 3.167 & .863 \\
\hline Awards given to business organizations for sustainability performance & 3.093 & .896 \\
\hline Coercive pressure & 3.250 & .458 \\
\hline Normative pressure & 3.182 & .530 \\
\hline Mimetic pressure & 3.083 & .744 \\
\hline
\end{tabular}

Table 1: Descriptive Analysis of Actual Influence of Factors

Source: Field Survey (2015)

Factor analysis is employed to ascertain the structure underlying the 22 items on the factors influencing sustainability reporting scale. The suitability of the data for factor analysis was checked. The Kaiser Meyer-Oklin value is 0.783, exceeding the recommended value of 0.6 in Pallant (2011). The Barlett's Test of Sphericity reaches statistical significance $(p=0.000)$, supporting the factorability of the correlation matrix. In the correlation matrix table, correlation coefficients of 0.3 and above are seen. Using Kaiser's criterion, the researcher is interested only in components with an Eigen value of greater than or equals to 1. The first five components record Eigen values of greater than 1 (8.689, 2.808, 1.762, 1.404 and 1.223). These five components explain a total of 66.65 percent of the variance. On the scree plot, a change in the shape of the plot is seen from component 4. This implies that components 1, 2, 3 and 4 explains or captures much more of the variance than the remaining components.

The component matrix table shows the unrotated loadings of each of the items on the four components. Most of the items on components 1, 2, 3 and 4 loads quite strongly (that is, the values are above 0.4). This suggests that a four-factor solution is likely to be more appropriate. The Rotated Component Matrix table shows the item loadings on the 4 -factor with component 1, 2, 3 and 4 explaining 66.65 percent of the variance. Rotated Component matrix shows the factor loadings of each of the variables. The highest loading on each component was searched for to identify and label the component. The Table below shows the Rotated Component Matrix for Principal Component Analysis with Varimax Rotation of four-factor solution of factors influencing sustainability reporting. 


\begin{tabular}{|c|c|c|c|c|}
\hline & \multicolumn{4}{|c|}{ Component } \\
\hline & 1 & 2 & 3 & 4 \\
\hline Human resources on sustainability & .849 & & & \\
\hline $\begin{array}{l}\text { Awards given to business organizations for } \\
\text { sustainability performance }\end{array}$ & .771 & & & \\
\hline $\begin{array}{l}\text { Use of assurance services on sustainability reporting } \\
\text { by business organizations }\end{array}$ & .673 & & & \\
\hline Accounting Firm Provision of Assurance Services & .671 & & & \\
\hline $\begin{array}{l}\text { Rating of organization on the basis of sustainability } \\
\text { performance }\end{array}$ & .668 & & & \\
\hline Presence in Foreign country & .581 & & & \\
\hline $\begin{array}{l}\text { Professional Association Training of Accounting } \\
\text { Professionals }\end{array}$ & .476 & & & \\
\hline Total Assets & & 817 & & \\
\hline Reverue Base & & .762 & & \\
\hline $\begin{array}{l}\text { Consumers Concern in Sustainable Products and } \\
\text { Services }\end{array}$ & & .720 & & \\
\hline $\begin{array}{l}\text { Reporting Practices of the Most Successful in the } \\
\text { Industry }\end{array}$ & & 719 & & \\
\hline Pressure from board of directors & & .709 & & \\
\hline Employee Attitude & & .633 & & \\
\hline Investor Concern in long-term performance & & .478 & & \\
\hline $\begin{array}{l}\text { Central Bank of Nigeria (CBN) Sustainability Banking } \\
\text { Principles }\end{array}$ & & & .779 & \\
\hline $\begin{array}{l}\text { Securities and Exuchange Commission (SEC) Code of } \\
\text { Corporate Governance }\end{array}$ & & & .756 & \\
\hline Initiation from the Chief Executive Officer & & & .634 & \\
\hline Employee Training & & & .623 & \\
\hline $\begin{array}{l}\text { Professional Firm Training of Accounting } \\
\text { Professionals }\end{array}$ & & & .519 & \\
\hline $\begin{array}{l}\text { Local lenders approving loans on the basis of } \\
\text { sustainability performance }\end{array}$ & & & & .827 \\
\hline Membership of external sovernance bodies & & & & .690 \\
\hline $\begin{array}{l}\text { Foreign Lenders approving loans on the basis of } \\
\text { sustainability performance }\end{array}$ & & & & .589 \\
\hline
\end{tabular}

Table 2: Rotated Component Matrix for PCA with Varimax Rotation of Four-Factor Solution of Factors Influencing Sustainability Reporting

Source: Field Survey (2015)

The Pearson correlation coefficients showed that there are significant associations between the level of sustainability reporting and mimetic, normative and coercive factors.

\begin{tabular}{|c|c|c|c|c|c|}
\hline & & $\begin{array}{c}\text { Extent of } \\
\text { Sustainability } \\
\text { Reporting }\end{array}$ & $\begin{array}{l}\text { Mean } \\
\text { Mimetic }\end{array}$ & $\begin{array}{c}\text { Mean } \\
\text { Normative }\end{array}$ & $\begin{array}{c}\text { Mean } \\
\text { Coercive }\end{array}$ \\
\hline \multirow{3}{*}{$\begin{array}{l}\text { Extent of } \\
\text { Sustainability } \\
\text { Reporting }\end{array}$} & $\begin{array}{l}\text { Pearson } \\
\text { Correlation }\end{array}$ & 1 & .218 & $.406^{-4}$ & $.377^{\circ}$ \\
\hline & Sig.(2-tailed) & & .114 & .002 & .005 \\
\hline & $\mathrm{N}$ & 54 & 54 & 54 & 54 \\
\hline \multirow[t]{3}{*}{ Mean Mimetic } & $\begin{array}{l}\text { Pearson } \\
\text { Correlation }\end{array}$ & .218 & 1 & $.676^{-}$ & $.681^{+4}$ \\
\hline & Sig. (2-tailed) & .114 & & .000 & .000 \\
\hline & $\mathrm{N}$ & 54 & 54 & 54 & 54 \\
\hline \multirow[t]{3}{*}{$\begin{array}{l}\text { Mean } \\
\text { Normative }\end{array}$} & $\begin{array}{l}\text { Pearson } \\
\text { Correlation }\end{array}$ & $.406^{-4}$ & $.676^{+-}$ & 1 & $.717^{\prime \prime}$ \\
\hline & Sig-(2-tailed) & .002 & .000 & & .000 \\
\hline & $\mathrm{N}$ & 54 & 54 & 54 & 54 \\
\hline \multirow[t]{3}{*}{ Mean Coercive } & $\begin{array}{l}\text { Pearson } \\
\text { Correlation }\end{array}$ & $.377^{4}$ & $.681^{+4}$ & $.717^{-1}$ & 1 \\
\hline & Sig. (2-tailed) & .005 & .000 & .000 & \\
\hline & $\mathrm{N}$ & 54 & 54 & 54 & 54 \\
\hline
\end{tabular}

Table 3: Pearson Correlations

\section{Discussions and conclusions}

\subsection{Discussions}

The survey responses generally show that managers acknowledge the role of institutional pressures stemming from within and outside the business organization. The results of this study suggest that the Securities and Exchange Commission (SEC) code of corporate governance is a core coercive factor 
influencing companies towards sustainability reporting. This finding is based on the positive response to the SEC code of corporate governance being an actual factor that has influenced companies' sustainability reporting. It is also interesting to note that the results of this study suggest that the influence of this study appear to suggest that the influence of the chief executive officer, investors concern with long-term performance of an organization, was rated stronger than the influence of presence of business organization in a foreign country. It may be that the presence of a business organization in a foreign country is not an automatic license for the organization in Nigeria to engage in sustainability reporting. In agreement with the finding of this study, Asaolu et al. (2011) note that multinational oil and gas companies operating in Nigeria were deficient in reporting sustainability issues. Multinational companies have operations in foreign countries and it does not seem that their Nigerian-based counterparts are made to engage in sustainability reporting by their foreign-based counterparts.

In line with the findings of Dobbs and Van Staden (2011), this study finds the influence of the $\mathrm{CEO}$ of a business as a key factor in driving sustainability reporting. This CEO's influence may be in form of establishment of goals towards sustainability performance and ultimately reporting. Investors are a class of business stakeholders who are often viewed as the dominant stakeholders (see Dobbs and Van Staden, 2011). It may not be surprising that respondents rate their influence in strong positive terms. It is also obvious from the survey results that mimetic pressures have the lowest mean score. This implies the absence of uncertainty associated with sustainability reporting.

This study finds that normative and coercive factors are responsible for the level of sustainability reporting among selected companies in Nigeria. The survey finds significant relationship between normative and coercive isomorphism and level of sustainability reporting. The findings of this study agree with Jalaludin et al. (2011) where mimetic pressure are not found to influence environmental management accounting practices. However, coercive and normative pressures are found to be associated with the adoption of such accounting practices. A reason for the absence of mimetic pressures in influencing companies' accounting practices in relation to environmental sustainability is that managers did not face uncertainty and there were policies and consultants that guided the course of adopting accounting practices in relation to environmental sustainability.

Based on theoretical propositions of DiMaggio and Powell (1983), it is expected that factors in an organization's institutional environment which is made up of coercive, normative and mimetic pressures, shape disclosure and reporting practices. Although, decision makers in companies opine that a mix of coercive, normative and mimetic factors are institutional pressures influencing sustainability reporting, only coercive and normative pressures are actually associated with sustainability reporting. For companies to engage in sustainability reporting, accounting professionals need to be trained by professional associations and professional firms. Based on the perceptions of decision makers in companies, there is a tendency for companies to be influenced by the reporting practices of the most successful company in the industry. Industry leaders need to be proactive about sustainability reporting. Companies also need to train their employees to appreciate the benefits of sustainability reporting. Also, a company's revenue and total assets base are determinants of sustainability reporting. These findings point to the need for large organizations to engage in sustainability reporting. The findings of this study suggest that normative and coercive forces may have been responsible for the level of sustainability reporting among the selected companies in the four sectors. Based on the new institutional theory, normative pressures from professional accounting associations, accounting firms, external governance bodies, human resources on sustainability, raters of sustainability performance, awards for sustainability performance are important in influencing sustainability reporting by companies. Companies need to subscribe to normative forces such as networking and education arising from professionalism to improve their level of sustainability reporting.

\subsection{Conclusions}

The current study suggests that coercive pressures from regulators, investors, consumers and finance providers are factors that influence sustainability reporting. These pressures are important because organizations could be denied resources when they fail to engage in promotion of reporting practices that show it takes cognizance of both business and society. The findings of this study have implications for research in less developed countries such as Nigeria. Research in other less developed 
countries should provide comparative platforms and shed light on the nature of pressures influencing sustainability reporting that are dominant across countries within a particular continent and roles that governance systems play in corporate disclosure and reporting practices. It is also crucial to decipher the trend in institutional pressures across time periods.

The results of this study could be of interest to professional accounting bodies and accounting firms because they provide normative pressures for companies to engage in sustainability reporting. Companies need to take a positive stance on employee training pertaining to sustainability reporting in order to improve their engagement in sustainability reporting. Accounting firms need to improve on their services to companies in the area of providing assurance on sustainability reporting. Successful industry leaders need to lead in the area of sustainability reporting practices. It is not enough for them to lead in terms of profitability alone as they should show that they operate to make the society a better place.

\section{Research limitations and direction for further research}

The findings of this study are subject to limitations. For instance, this study is based on a survey undertaken in a one-year period. The results of this study were based on perceptions of respondents using questionnaire. Future studies can employ interviews to gain more in-depth understanding of the role of the factors identified. Future studies based on new institutional theory can assess the influence of other institutions such as trade unions, environmental pressure groups, employee unions and trade creditors. Also, there is need to expand the survey to organizations in other industrial sectors such as conglomerates, agriculture, natural resources, insurance and telecommunications.

\section{References}

Adams, C.A. (2002) Internal organizational factors influencing corporate social reporting: Beyond current theorising. Accounting, Auditing \& Accountability Journal, 15(2), 223-250.

Adams, C.A. \& Frost, G. (2008) Integrating sustainability reporting into management practices. Accounting Forum, 32(4), 288-302.

Adams, C.A. \& Larrinaga-Gonzalez, C. (2007) Engaging with organizations in pursuit of improved sustainability accounting and performance. Accounting, Auditing $\mathcal{E}$ Accountabilty Journal, 20(3), 333355.

Amran, A. \& Devi, S. (2008) The impact of government and foreign affiliate influence on corporate social reporting: The case of Malaysia. Managerial Auditing Journal, 23(4), 386-404.

Asaolu, T.O., Agboola, A.A., Ayoola, T.J. and Salawu, M.K. (2011) 'Sustainability reporting in the Nigerian oil and gas sector', Paper presented at the Environmental Management Conference, Federal University of Agriculture, Abeokuta, Nigeria. Available from:

http://journal.unaab.edu.ng/index.php/COLERM/article/view/238/221 (Accessed 14 June 2014).

Baele, A. (2012) The CEO's perception on CSR: A determinant of CSR reporting. Unpublished Master Thesis. Ghent University, Belgium. Available from:

http://lib.ugent.be/fulltxt/RUG01/001/893/406/RUG01-001893406_2012_0001_AC.pdf (Accessed 14 June 2015).

Baker, R.C. \& Bettner, M.S. (1997) Interpretive and critical research in accounting: A commentary on its absence from mainstream accounting research. Critical Perspectives on Accounting, 8(4), 293-310.

Baron, R. (2014) The evolution of corporate reporting for integrated performance. Available from:

https://www.oecd.org/sdroundtable/papersandpublications/The $\% 20$ Evolution $\% 20$ of $\% 20$ Corporate $\% 20$ Reporting $\% 20$ for $\% 2$ OIntegrated\%20Performance.pdf (Accessed 20 May 2015).

Bebbington, J., Higgins, C. \& Frame, B. (2009) Initiating sustainable development reporting: Evidence from New Zealand. Accounting, Auditing \& Accountability Journal, 22(4), 588-625.

Brennan, N.M. \& Solomon, J. (2008) Corporate governance, accountability and mechanisms of accountability: An overview. Accounting, Auditing \& Accountability Journal, 2(7), 885-906.

DiMaggio, P.J. \& Powell, W.W. (1983) The iron cage revisited: institutional isomorphism and collective rationality in organizational fields. American Sociological Review, 48(2), 147-160. 
Farneti, F., \& Rammal, H.G. (2013) 'Sustainability reporting in the Italian public sector: Motives and influences', Proceedings of the Seventh Asia Pacific Interdisciplinary Research in Accounting Conference, Kobe, Japan, 26-28 July, pp. 1-22. Available from:

http:/ / www.apira2013.org/proceedings/pdfs/K137.pdf (Accessed 10 July 2016)

Fremond, O. (2000) The role of stakeholders. Available from:

https:// www.oecd.org/daf/ca/corporategovernanceprinciples/1930657.pdf (Accessed 15 July 2015).

Global Reporting Initiative (2013) Sustainability reporting guidelines version G4.

Available from: http://www.globalreporting.org/resourcelibrary/GRIG4-Part1-Reporting-Principlesand-Standard-Disclosures.pdf (Accessed 10 June 2014).

Goswami, K. \& Lodhia, S. (2012) Influences on sustainability reporting practices in selected South Australian local councils: An explanatory case study. Available from:

http:/ / ro.uow.edu.au/cgi/viewcontent.cgi?article=1023\&context=acsear2012 (Accessed 10 July 2016).

Hendey, E. (2013) Does divestment work? Available from: http://www.iop.harvard.edu/does-divestmentwork (Accessed 10 May 2014).

Jalaludin, D., Sulaiman, M. \& Ahmad, N.N.N. (2011) Understanding environmental management accounting (EMA) adoption: A new institutional sociology perspective. Social Responsibility Journal, $7(4), 540-557$.

Kaspereit, T. \& Lopatta, K. (2011) The value relevance of SAM's corporate sustainability ranking and GRI sustainability reporting in the European stock markets. Available from:

papers.ssrn.com/sol3/papers.cfm? abstract_id=1976224 (Accessed 9 January 2014).

Kaspersen, M. (2013) The construction of social and environmental reporting. Available from:

http://openarchive.cbs.dk/bitstream/handle/10398/8667/Mia_Kaspersen_Summary.pdf?sequence=3 (Accessed 11 January 2015).

KPMG (2008) Sustainability reporting: A gude. Available from:

http://www.kpmg.com/CN/en/IssuesAndInsights/ArticlesPublications/Document s/sustainableguide-0811.pdf (Accessed 18 March 2014).

Krongkaew-Arreya, N., \& Setthasakko, W. (2013) Influence factors to develop sustainability report: A case study of Thailand. Paper presented at the $8^{\text {th }}$ Annual London Business Research Conference, Imperial College, London, United Kingdom, 8-9 July, pp. 1-11. Available from:

www.wbiworldconpro.com/pages/paper/london-conference-2013/460 (Accessed 14 January 2016).

Mitra, P.K., Agrawal, V. \& Ghosh, A. (2015) Exploring the factors for effective sustainability reporting: A survey of Indian chemical industry. Asian Social Science, 11(3), 197-211.

Mohd-Saleh, N., Mohd-Sanusi, Z., Abd-Rahman, Z. \& Bukit, R. (2012) Firm performance, CEO tenure and corporate governance reporting in Malaysia. International Journal of Management Practice, 5(2), 170189.

Muswaka, L. (2014) The two-tier board structure and co-determination: Should South Africa follow

the Germany example? Mediterranean Journal of Social Sciences, 5(9), 142-147.

Nigerian Stock Exchange (2015) The Nigerian Stock Exchange: Listed companies.

Available from: http://www.nse.com.ng/Issuers-section/listed-securities/listed-companies (Accessed 12 August 2015).

Pallant, J. (2011) SPSS survival manual: A step by step guide to data analysis using SPSS. Australia: Allen \& Unwin.

Ricart, J.E., Rodriguez, M.A., \& Sanchez, P. (2004) Sustainability in the boardroom: An empirical examination of Dow Jones Sustainability world index leaders. Available from

http://www.iese.edu/en/files/sustainability_tcm4-15942.pdf (Accessed 10 April 2012)

Sciulli, N. (2011) Influences on sustainability reproting within local governments. International Review of Business Research Paper, 7(2), 282-291.

Sufian, M.A. (2012). Corporate social responsibility disclosure in Bangladesh. Global Journal of Management and Business Research, 12(14), 149-155. 
Appendix 1: Institutiona1 Pressure Factors

7 Coercive Pressures

The investors in this organization are concerned with long-term performance

This organization is guided by the Securities and Exchange Commission (SEC) Code of Corporate Governance guidelines for sustainability reporting

This organization is guided by the Central Bank of Nigeria (CBN) Sustainability Banking Principles on sustainability reporting

The Consumers of the products and services of this organization are interested in sustainable products and services

The revenue base of this organization is high

The total asset base of this organization is high

Foreign lenders emphasize on approving loans on the basis of sustainability performance of an organization

Local lenders emphasize on approving loans on the basis of sustainability performance of an organization

Normative Pressures

The Chief Executive Officer of my organization initiates sustainability reporting

The Board of Directors of my organization pressures this organization to engage in sustainability reporting

Employees in this organization are trained on sustainability reporting

Accounting professionals in this organization subscribe to training on sustainability reporting by Professional Accounting Associations in Nigeria

Accounting professionals in this organization subscribe to training on sustainability reporting by Professional Accounting Firms in Nigeria

This organization is a corporate member of external governance bodies such as United Nations Environment Programme (UNEP), global oil and gas industry association for environmental and social issues (IPIECA), and United Nations Global Compact (UNGC)

There are sustainability officers in this organization

Employees' attitude towards sustainability reporting is encouraging

Accounting firms provide assurance services on sustainability reporting to this organization

This organization uses assurance services on sustainability reporting provided by accounting firms

This organization is rated by external parties on the basis of sustainability performance

This organization has received awards on the basis of sustainability performance

Mimetic Pressures

This organization looks up to Successful Industry Leaders' sustainability reporting This organization has presence abroad and this influences her sustainability reporting 